\title{
Regulation of Hematopoietic Stem Cell Fate: Self-Renewal, Quiescence and Survival
}

\author{
Yasushi Kubota ${ }^{1,2}$ and Shinya Kimura ${ }^{1}$ \\ ${ }^{1}$ Division of Hematology, Respiratory Medicine and Oncology, \\ Department of Internal Medicine, Faculty of Medicine, Saga University \\ ${ }^{2}$ Department of Transfusion Medicine, Saga University Hospital
}

Japan

\section{Introduction}

Hematopoietic stem cells (HSCs) are probably the most extensively characterized somatic stem cells and are the only stem cells that have been clinically used to treat diseases such as leukemia, germ cell tumors, and congenital immunodeficiencies. Because of their capacity for self-renewal and their ability to differentiate into different lineages, HSCs are able to continually replenish the cells that make up the hematopoietic system (Kondo et al., 2003). Decades of intensive study using multicolor cell sorting techniques have allowed investigators to identify these cells within a small population in the mouse bone marrow (BM) (i.e., CD34low/-, $\mathrm{Kit}^{+} \mathrm{Sca}-1^{+}$lineage marker-negative cells: CD34low/- KSL) and thereby allow the prospective isolation of nearly-homogenous HSC populations for further characterization (Osawa et al., 1996).

Under steady-state conditions, the majority of HSCs are maintained in a quiescent state in which they divide infrequently to produce proliferative progenitors that eventually give rise to the mature hematopoietic cells that sustain blood homeostasis (Cheshier et al., 1999). However, in response to external stresses such as bleeding, myeloablative chemotherapy and total body irradiation, HSCs proliferate extensively to produce very high numbers of primitive progenitor cells, thereby enabling rapid hematological regeneration (Randall et al., 1997). Once recovery from myelosuppression has been achieved, the activated HSCs return to a quiescent state via a number of negative feedback mechanisms (Venezia et al., 2004). The cell fate decisions (including life and death, self-renewal and differentiation) of HSCs are important processes that regulate the number and lifespan of the HSC pool within a host. Defects in these processes may contribute to hematopoietic failures and to the development of hematologic malignancies.

Understanding the molecular mechanisms underlying HSC regulation is of great importance to basic stem cell biology and for the development of HSCs for use in various clinical applications. Information regarding the regulation of HSC fate has been gained using conventional experimental approaches such as gene deletion, gene overexpression, and the direct stimulation of HSCs with cytokines. Although many studies have elucidated the factors controlling HSC fate using these methods, they can occasionally be misleading 
because they lack physiological relevance and do not identify phenomena such as genetic redundancy. For example, family genes or alternative pathways can compensate functionally for deleted genes in gene-ablated mouse models in a manner that masks the true physiology. One approach to identifying the individual components involved in the molecular pathways underlying HSC regulation is to define the molecular signature of the HSCs by comparative transcriptional profiling of distinct subsets of hematopoietic cells. Over the past decade, several attempts have been made by independent investigators, including ourselves, to define the molecular signature of HSCs (Park et al., 2002; RamalhoSantos et al., 2002; Ivanova et al., 2002; Akashi et al., 2003; Venezia et al., 2004; Zhong et al., 2005; Forsberg et al., 2005; Ramos et al., 2006; Chambers et al., 2007; Kubota et al., 2009). A list of gene expression profiling studies using purified mouse HSCs performed to date is shown in Table 1. Although this information has, more or less, clarified the molecular makeup of HSCs and several critical factors have been identified based on the data reported in these studies, it is still extremely time-consuming to elucidate the physiological function of each individual gene involved in HSC regulation. The transcriptional regulation of stem cell fate, particularly by factors that have specific functions in HSCs, is only beginning to be understood.

In this chapter, we briefly review the recent advances in our knowledge of cell-intrinsic regulators of HSC self-renewal, differentiation, quiescence, cycling, and survival.

\begin{tabular}{|c|c|c|c|c|}
\hline & Year & HSC phenotype & Compared population & References \\
\hline Parket al. & 2002 & Rho $0^{\text {low }} \mathrm{KSL}$ & Rho $^{\text {high }} \mathrm{KSL}$ & Blood 99(2):488-498. \\
\hline Ramalho-Santos et al. & 2002 & $\mathrm{CD} 34^{-1 / 0 w} \mathrm{KSL}-\mathrm{SP}$ & MP & Science 298(5593):597-600. \\
\hline Ivanova et al. & 2002 & Rholow KSL & Rho ${ }^{\text {high }}$ KSL, LCP, MBC & Science 298(5593):601-604. \\
\hline Akashi et al. & 2003 & Rho $0^{\text {low }}$ Thy-1.1 $1^{\text {low }} \mathrm{KSL}$ & LMPP, CLP, CMP & Blood 101(2):383-389. \\
\hline Venezia et al. & 2004 & Sca- $1^{+}-\mathrm{SP}$ & 5-FU treated SP & PLoS Bio/2(10):e301. \\
\hline Zhong et al. & 2005 & $\mathrm{CD} 34^{-\mathrm{CD}} 38^{+} \mathrm{KSL}$ & $\mathrm{CD} 8^{+}$or $\mathrm{CD} 38^{-\mathrm{CD}} 34^{+} \mathrm{KSL}$ & PNAS102(7):2448-2453. \\
\hline Kiel et al. & 2005 & Thy $1.1^{\text {low }} K S L$ & Thy $-1.1^{10} \mathrm{Sca}-1^{+} \mathrm{Mac}-1^{10} \mathrm{CD} 4^{\mathrm{l}} \mathrm{B} 220^{-}$ & Cell121(7):1109-1121. \\
\hline Forsberg et al. & 2005 & FIK2-Thy $1.1^{\text {low }} \mathrm{KSL}$ & Thy $1.1^{\text {low, }}$ Thy $1.1^{-} \mathrm{Flk} 2+\mathrm{KSL}$ & PLoS Genet 1(3):e28. \\
\hline Ramos et al. & 2006 & $\mathrm{Sca}-1^{+} \mathrm{Gr} 1^{-}-\mathrm{SP}$ & $\mathrm{CD} 8^{+}$Tcell & PLoS Genet2(9):e159. \\
\hline \multirow[t]{2}{*}{ Chambers et al. } & 2007 & KSL-SP & Erythrocyte Granulocyte Native T & Cell Stem Cell 1(5):578-591. \\
\hline & & & Activated T B-cell Monocyte NK & \\
\hline Kubota et al. & 2009 & $\mathrm{CD}^{- \text {-llow }} \mathrm{KSL}$ & $\mathrm{CD} 34^{+} \mathrm{KSL}$ & Blood 114(20):4383-4392. \\
\hline
\end{tabular}

Rho, rhodamine; SP, side population; LCP, lineage-committed progenitor; $\mathrm{MBC}$, mature blood cell;

MPP, multipotent progenitor; CLP, common lymphoid progenitor; CMP, common myeloid progenitor

Table 1. Gene expression profiling analyses of adult HSCs

\section{Regulators of HSC fate}

\subsection{Regulation of HSC self-renewal and quiescence}

The outstanding feature of adult stem cells is their relative quiescence (Orford et al., 2008; Wilson et al., 2008). Quiescence is critical for the maintenance and self-renewal of HSCs. Unscheduled HSC proliferation results in the loss of self-renewal or stem cell exhaustion (Orford et al., 2008; Wilson et al., 2009; Trumpp et al., 2010). Identification of the molecules 
that regulate adult HSCs has largely been achieved through the use of gene-targeted mouse models. Increasing or decreasing HSC cell-cycling results in the accelerated production of more committed progenitors at the expense of self renewal, or the insufficient production of progeny cells, which eventually results in BM failure.

\subsubsection{Positive regulation}

\subsubsection{GATA-2}

GATA-2 is highly expressed in immature progenitors within hematopoietic lineages (Tsai \& Orkin, 1997; Akashi et al., 2000). The haploinsufficient GATA-2+/- mouse model shows mildly increased quiescence of both HSCs and progenitor cells (Rodrigues et al., 2005). However, Tipping et al. recently showed that enforced expression of GATA-2 in a murine cell line (Ba/F3), or human cord blood HSCs $\left(\mathrm{CD} 34^{+} \mathrm{CD} 38^{-}\right)$and progenitors $\left(\mathrm{CD} 34^{+} \mathrm{CD} 38^{+}\right)$, increases quiescence and inhibits proliferation (Tipping, et al, 2009).

\subsubsection{Bmi1}

Bmi1 belongs to the polycomb group (PcG) of proteins, which play a role in the transcriptional repression of genes via histone modification (Rajasekhar et al., 2007). Bmi1 is highly expressed in HSCs. The expression of Bmi1 is maintained at high levels in lymphoid lineage cells but is downregulated during myeloid differentiation (Iwama et al., 2004). Although Bmi1-/- mice show normal fetal liver hematopoiesis, progressive pancytopenia emerges in postnatal $\mathrm{Bmi1} /$ - mice. This hematopoietic defect can be attributed to impaired HSC self-renewal. Transplanted fetal liver and bone marrow cells from Bmi1 /- mice cannot contribute to long-term hematopoiesis, although they do maintain the ability to repopulate in the short-term (Park et al., 2003; Iwama et al., 2004). Conversely, enforced expression of Bmi1 promotes HSC self-renewal (Iwama et al., 2004). Thus, Bmi1 is essential for the maintenance of HSC self-renewal.

The activity of Bmi1 in HSCs largely depends on the silencing of its target, the Ink4a locus (Jacobs et al., 1999). The expression of $p 16^{I N K 4 a}$ and P19ARF (both cell-cycle inhibitors encoded by the Ink $4 a$ locus) is markedly upregulated in hematopoietic cells in Bmi1-deficient mice, and the overexpression of $p 16^{I N K 4 a}$ and $p 19$ ARF in HSCs induces cell-cycle arrest and p53-dependent apoptosis (Park et al., 2003). On the contrary, the deletion of both $p 16^{I N K 4 a}$ and $p 19^{A R F}$ restores the self-renewal ability of Bmi1-/- HSCs (Oguro et al., 2006). Thus, Bmi1 prevents the premature loss of HSCs by repressing the p16 $6^{\mathrm{INK} 4 \mathrm{a}}$ and $\mathrm{p} 19 \mathrm{ARF}-$ dependent senescence pathways.

\subsubsection{Gfi-1}

Gfi1 is a SNAG-domain-containing zinc-finger transcriptional repressor, which plays a role in T cell proliferation and the development of lymphoid tumors (Gilks et al., 1993). It is suggested that Gfi-1 restricts proliferation and preserves functional integrity of hematopoietic stem cells. Gfi-1-null HSCs show excessive cell cycling and a decreased capacity for self-renewal in competitive repopulation assays (Hock et al., 2004; Zeng et al., 2004).

\subsubsection{Pbx1}

Pbx1 is a TALE class homeodomain transcription factor that critically regulates numerous embryonic processes, including hematopoiesis (DiMartino et al., 2001). Although a potential 
role was suggested by the observation that $\mathrm{Pbx} 1$ is preferentially expressed in long-term repopulating HSCs (LT-HSCs) compared with more mature progenitor cells (Forsberg et al., 2005), its functional analysis in adult HSCs has been hampered because Pbx1 mutant mice are embryonic lethal. Therefore, Pbx1-conditional knockout $(\mathrm{KO})$ mice have been used to study the role of Pbx1 in the adult mouse hematopoietic system (Ficara et al., 2008). Conditional inactivation of Pbx1 in hematopoietic cells results in the loss of HSCs, which is associated with decreased quiescence. This leads to a defect in the maintenance of selfrenewal in serial transplantation assays. Global gene expression profiling analyses show that a significant proportion $(\sim 8 \%)$ of the downregulated genes in Pbx1-deficient HSCs belong to the TGF- $\beta$ signaling pathway, which has been implicated in maintaining HSC quiescence (Yamazaki et al., 2009). Also, in contrast to WT LT-HSCs, Pbx1-mutant LT-HSCs do not upregulate the expression of several downstream transcripts in response to TGF- $\beta$ stimulation in vitro. These results suggest that Pbx1 regulates HSC self-renewal and quiescence, at least in part by affecting the response to TGF- $\beta$.

\subsubsection{Evi-1}

The ecotropic viral integration site-1 (Evi-1) was first identified in murine model systems as the integration site for the ecotropic retrovirus that causes myeloid leukemia (Morishita et al., 1988; Mucenski et al., 1988). Several studies using gene-targeting mice show that Evi-1 is required for HSC regulation. Yuasa et al. showed that Evi-1 is preferentially expressed in HSCs in embryos and adult BM. Evi-1-deficient embryonic HSCs are severely decreased in number, and show defective repopulating capacity. In addition, the expression of GATA-2 mRNA is markedly reduced in HSCs from Evi-1-null embryos. GATA-2 promoter analysis revealed that Evi-1 directly binds to the GATA-2 promoter and acts as an enhancer (Yuasa et al., 2005). Another study using conditional Evi-1 knockout mice showed that Evi-1 also regulates adult HSC proliferation in a dose-dependent manner. Evi-1-deficient BM HSCs did not maintain definitive hematopoiesis and lost their ability to reconstitute the cell population. Mutant mice heterozygous for Evi-1 exhibited an intermediate phenotype in terms of HSC activity (Goyama et al., 2008). Furthermore, gene expression profiling of Evi1-deleted HSCs and leukemic cells identified Pbx1 as a downstream target for Evi-1 in HSCs (Shimabe et al., 2009).

\subsubsection{JunB}

The AP-1 transcription factor, JunB, is a transcriptional regulator of myelopoiesis and a potential tumor suppressor gene in mice (Passegue et al., 2001). Compared with normal HSCs, JunB-deficient LT-HSCs showed an average 2-fold increase in the percentage of cycling cells, suggesting that JunB functions to limit cell-cycle entry. Gene expression analyses revealed that JunB-deficient LT-HSCs show increased expression of cyclins and decreased expression of cyclin-dependent kinase inhibitors (Santaguida et al., 2009). These results suggest that the absence of JunB induces quiescent cells to enter the cell cycle.

\subsubsection{7 p53}

The p53 tumor suppressor protein functions as a transcription factor, regulating the transcription of genes that induce cell-cycle arrest, senescence, and apoptosis. LT-HSCs express high levels of p53 (Dumble et al., 2007). Although p53-deficient mice show almost 
normal hematopoiesis (Lotem \& Suchs., 1993), a number of studies have identified a role for p53 in the proliferation, differentiation, apoptosis, and aging of HSCs (Kastan et al., 1991; Shounan et al., 1996; Park et al., 2003; Dumble et al., 2007). Recent detailed analyses of p53null mice have unraveled other important functions of p53 in HSCs. Liu et al. found that p53 promotes HSC quiescence, and that p53-deficient HSCs enter the cell cycle more easily (Liu et al., 2009). Competitive BM repopulation assays revealed that p53-null cells out-compete wild-type cells (TeKippe et al., 2003; Chen et al., 2008; Liu et al., 2009), indicating that p53 is a negative regulator of HSC self-renewal. In addition, Liu et al. also identified Gfi-1 and necdin as p53 target genes by performing comparative transcriptional profiling of HSCs isolated from wild-type and p53-deficient mice. The results of in vitro overexpression and knockdown experiments identified a role for necdin in the maintenance of HSC quiescence and self-renewal. However, necdin appears to have a modest functional role in HSCs in vivo (Kubota et al., 2009), and necdin overexpression does not result in enhanced HSC quiescence (Sirin et al., 2010).

\subsubsection{Nurr1}

Gene expression profiling analyses identified Nurr1 (also known as Nr4a2), an orphan nuclear receptor, as a candidate molecule that may play a functional role in HSC quiescence (Venezia et al., 2004; Chambers et al., 2007). Overexpression of Nurr1 resulted in HSC quiescence. On the other hand, loss of one Nurr1 allele resulted in enhanced cycling and sensitivity to the chemotherapeutic agent 5-fluorouracil (5-FU). Molecular analysis showed that Nurr1 overexpression is positively correlated with the upregulation of the cell-cycle inhibitor p18INK4C, suggesting a mechanism by which Nurr1 may regulate HSC quiescence (Sirin et al., 2010).

\subsubsection{Reactive oxygen species, FoxOs}

Reactive oxygen species (ROS) play an important role in the regulation of HSC quiescence. The forkhead O (FoxO) family of transcription factors (FoxO1, FoxO3, FoxO4, and FoxO6) participates in various cellular processes, including the induction of cell-cycle arrest, stress resistance, apoptosis, differentiation, and metabolism (Greer \& Brunet., 2005). Two groups reported that FoxOs play a regulatory role in a number of physiologic processes that influence HSC numbers and function. Both aged germline FoxO3-deficient mice and conditional triple knockout (FoxO1, 3, 4) mice show a reduction in HSC numbers with a deficient repopulating capacity in competitive reconstitution assays and serial competitive transplantation assays (Tothova et al., 2007; Miyamoto et al., 2007). These phenotypes correlate with increased cell-cycling and apoptosis of HSCs, caused by increased levels of ROS. Furthermore, treatment with the antioxidant, N-acetyl-L-cysteine (NAC), rescues the FoxO-deficient HSC phenotype.

\subsubsection{Fbxw7}

Fbxw7 is the F-box protein subunit of an SCF-type ubiquitin ligase complex that targets positive regulators of the cell-cycle, including Notch, c-Myc, cyclin E, and c-Jun. Two independent groups investigated the functions of Fbxw7 in HSCs using conditional Fbxw7 knockout mice (Matsuoka et al., 2008; Thompson et al., 2008). Conditional ablation of Fbxw7 rapidly and severely affects hematopoietic progenitor maintenance within the BM. Fbxw7-/HSCs show increased cycling and defective long-term repopulation capacity in competitive 
transplantation assays. As Fbxw7 is able to ubiquitinate several target proteins, studies were conducted to examine the protein expression of Notch1, c-Myc, and cyclin E. The results showed that c-Myc protein was substantially overexpressed in Fbxw7-/- HSCs, suggesting that the activation of the cell-cycle in Fbxw7-null HSCs induced by excess c-Myc causes the premature exhaustion of HSCs.

\subsubsection{HIF-1a}

Leukemic stem cells (LSCs) reside in the niches near epiphysis of the bone (Ishikawa et al., 2007) and oxygen concentration of this area is quite low. Thus, it may be very important for leukemic cells, especially for LSCs to survive and adapt to hypoxia (Takeuchi et al., 2010). Cellular responses to hypoxia are mediated by hypoxia-inducible factors (HIFs), which regulate gene expression to facilitate adaptation to hypoxic conditions (Kaelin \& Ratcliffe., 2008). Hypoxia inducible factor-1a (HIF-1a) is stabilized under low-oxygen conditions, such as those present in the BM. Recently, two groups investigated the importance of hypoxia and its related signaling pathways in HSC function using different approaches (Simsek et al., 2010; Takubo et al., 2010). HIF-1a levels are elevated in adult HSCs and its transcription is regulated by the homeodomain protein Meis1, which is essential for hematopoiesis (Hisa et al., 2004; Simsek et al., 2010). HIF-1a conditional knockout mice show that HIF-1adeficient HSCs have an increased cell cycling rate and show progressive loss of long-term repopulation ability in serial transplantation assays (Takubo et al., 2010). Taken together, these data indicate that the precise regulation of HIF-1a levels is required to maintain HSC quiescence.

\subsubsection{Lkb1}

The control of energy metabolism within HSCs is poorly understood, although they are highly sensitive to oxidative stress. Recently, several groups examined the role of the protein, Lkb1, in the metabolic regulation of HSCs (Nakada et al., 2010; Gurumurthy et al., 2010; Gan et al., 2010). Lkb1 is a kinase enzyme that regulates the activity of AMPactivated protein kinase (AMPK). Conditional inactivation of Lkb1 (Mx1-Cre; LKB1fl/fl or RosaCreERT2; LKB1L/L) in adult mice causes the loss of HSC quiescence, rapid HSC depletion, and pancytopenia. Interestingly, Lkb1 seems to regulate HSC homeostasis primarily through pathways that are independent of its downstream effectors, AMPK and mTORC1.

\subsubsection{Cyclin-dependent kinase inhibitors}

$\mathrm{p} 21^{\text {cip1/waf1 }}$ (hereafter referred to as p21) is a mammalian member of the CIP/KIP family and was the first cyclin-dependent kinase inhibitor to be identified (Serrano et al., 1993; Harper et al., 1993; Stier et al., 2003). Serial transplantation assays using p21-deficient cells showed premature HSC exhaustion; also, p21-null mice were more sensitive to 5-FU (Cheng et al., 2000). These results suggest that p21 restricts HSC entry into the cell cycle and regulates the size of the HSC pool under conditions of stress. However, a later study demonstrated that p21 plays a minor role in regulating HSC quiescence under conditions of steady-state hematopoiesis (van Os et al., 2007).

Although p57kip2 (hereafter referred to as p57) is highly expressed in HSCs (Table 2) (Kubota et al., 2009; Umemoto et al., 2005), little is known about its functional role. Microarray 
analysis studies of human CD34+ $\mathrm{HSC}$ / progenitor cells identified p57 as the only cyclindependent kinase inhibitor induced by TGF $\beta$ (Scandura et al., 2004). Knockdown of p57 in hematopoietic cell lines using small interfering RNA (siRNA) results in more rapid proliferation of hematopoietic cells in the absence of TGF- $\beta$. These results suggest that p57 is required for the TGF- $\beta$-mediated cell cycle entry of hematopoietic cells and for repressing the proliferation of these cells.

\begin{tabular}{|c|c|}
\hline Gene Name & Gene Symbol \\
\hline \multicolumn{2}{|l|}{ Apoptosis } \\
\hline serine (or cysteine) peptidase inhibitor, clade $A$, member $3 G$ & Serpina3g \\
\hline \multicolumn{2}{|l|}{ Cell surface } \\
\hline adhesion molecule with Ig like domain 2 & Amigo2 \\
\hline claudin 5 & Cldn5 \\
\hline junction adhesion molecule 2 & Jam2 \\
\hline vascular cell adhesion molecule 1 & Vcam1 \\
\hline \multicolumn{2}{|l|}{ Cell CydeRegulation } \\
\hline cyclin-dependent kinase inhibitor $1 \mathrm{C}$ (P57) & Cdkn1c \\
\hline \multicolumn{2}{|l|}{ Cell Signaling } \\
\hline frizzled homolog 4 (Drosophila) & Fzd4 \\
\hline insulin-like growth factor 1 & Igf1 \\
\hline interferon inducible GTPase 1 & ligp \\
\hline multiple PDZ domain protein & Mpdz \\
\hline nik related kinase & Nrk \\
\hline regulator of G-protein signaling 4 & Rgs4 \\
\hline ras homolog gene family, member $\mathrm{J}$ & Rhoj \\
\hline suppressor of cytokine signaling 2 & Socs2 \\
\hline \multicolumn{2}{|l|}{ Cellular Metabolism } \\
\hline cytochrome $\mathrm{P} 450$, family 4 , subfamily b, polypeptide 1 & Cyp4b1 \\
\hline fatty acid binding protein 4 , adipocyte & Fabp4 \\
\hline RIKEN cDNA 4432416J03 gene & 4432416J03Rik \\
\hline \multicolumn{2}{|l|}{ Endocyosis } \\
\hline intersectin $1(\mathrm{SH} 3$ domain protein $1 \mathrm{~A})$ & Itsn \\
\hline \multicolumn{2}{|l|}{ Extracellular } \\
\hline bone morphogenetic protein 2 & Bmp2 \\
\hline connective tissue growth factor & Ctgf \\
\hline nidogen 1 & Nid1 \\
\hline tissue factor pathway inhibitor & Tfpi \\
\hline tissue inhibitor of metalloproteinase 3 & Timp3 \\
\hline \multicolumn{2}{|l|}{ Transcription Factor } \\
\hline forkhead box $\mathrm{A} 3$ & Foxa3 \\
\hline kruppel-like factor 9 & Klf9 \\
\hline myeloid/lymphoid or mixed lineage-leukemia translocation to 3 homolog (Drosophila) & Milt3 \\
\hline necdin & Ndn \\
\hline nuclear protein $1(\mathrm{p} 8)$ & Nupr1 \\
\hline retinoid $\mathrm{X}$ receptor gamma & Rurg \\
\hline \multicolumn{2}{|l|}{ Unknown } \\
\hline tripartite motif-containing 47 & Trim47 \\
\hline RIKEN cDNA 2310051E17 gene & 2310051E17Rik \\
\hline RIKEN CDNA 2810432L 12 gene & 2810432L12Rik \\
\hline
\end{tabular}

Table 2. Genes expressed at higher levels in HSCs than in other subsets.

Genes showing at least 2-fold higher expression in CD34-/low KSL cells than in CD34+ KSL cells were selected by microarray analysis. The selected genes were then evaluated by QPCR, and genes whose transcripts were expressed at $\geq 2$-foltd higher levels in CD34-/low KSL cells than all other samples are listed. 


\subsubsection{Negative regulation}

\subsubsection{E3 ubiquitin ligase}

The E3 ubiquitin ligase, c-Cbl, is a member of the RING finger-type ubiquitin ligase $\mathrm{Cbl}$ (casitas B-cell lymphoma) family. The c-Cbl protein is thought to implement the degradation of various cellular proteins, receptors, and signaling molecules including Notch1, STAT5, and c-Kit (Jehn et al., 2002; Goh et al., 2002; Zeng et al., 2005). c-Cbl-deficient mice were used to study the role of c-Cbl in HSCs (Rathinam et al., 2008). The number of HSCs and progenitors was significantly higher in the $\mathrm{BM}$ of $\mathrm{c}-\mathrm{Cbl}$-null mice due to increased proliferation. Interestingly, detailed analyses revealed augmented STAT5 phosphorylation in $\mathrm{c}-\mathrm{Cbl} /$ - HSCs in response to TPO/c-MPL signaling which is crucial for the proliferation and self-renewal of HSCs (Kimura et al., 1998), and this led to enhanced c-Myc expression. C-Cbl-deficient HSCs also showed an increased repopulating ability in competitive reconstitution assays, including serial transplantation. These results suggest that c-Cbl acts as a negative regulator of both the size of the HSC pool and self-renewal (Rathinam et al., 2008).

Recently, Itch, another E3 ligase belonging to the HECT family (Bernassola et al., 2008), was also identified as a negative regulator of HSC homeostasis and function. The phenotype of Itch $\%$ - HSCs was similar to that of $c-C b l-/$ HSCs. However, unlike c-Cbl, Itch-deficient HSCs showed augmented Notch1 signaling. Furthermore, knockdown of Notch1 in Itch-null HSCs resulted in the reversion of the phenotype (Rathinam et al., 2011). Taken together, these studies underscore the pivotal roles of E3 ubiquitin ligases and the importance of posttranslational modification of HSCs in the molecular control of HSC self-renewal.

\subsubsection{Egr1}

Egr1 is a member of the immediate early response gene family (Gashler et al., 1995). Egr1 is highly expressed in LT-HSCs under steady-state conditions and is downregulated upon proliferative stimulation and migration in response to pharmacological mobilization (Min et al., 2008). Egr1-deficient mice show a significant increase in the frequency of cycling HSCs. This phenomenon results in a slightly higher frequency of HSCs in the BM of Egr1-/- mice. Interestingly, loss of Egr1 results in a striking increase (up to 10-fold) in the number of circulating HSCs. Importantly, HSCs isolated from both the BM and peripheral blood of Egr1\%- mice show a greater degree of long-term multi-lineage repopulation after transplantation, although their life span is slightly reduced. Quantitative RT-PCR analysis shows that Bmi1 is upregulated in Egr1\%- HSCs. In addition, Egr1\%- HSCs also show the downregulation of p21CIP1/WAF1 and increased expression of cyclin-dependent kinase 4 (cdk4), which is consistent with their increased cell-cycling status (Min et al., 2008). Taken together, the deletion of Egr1 causes an increase in the number of cycling HSCs but does not lead to stem cell exhaustion. This may be due to Bmi1 upregulation.

\subsubsection{Lnk}

Lnk is a member of an adaptor protein family that possesses a number of protein-protein interaction domains: a proline-rich amino-terminus, a pleckstrin homology $(\mathrm{PH})$ domain, a Src homology 2 (SH2) domain, and many potential tyrosine phosphorylation motifs (Rudd., 2001). Studies using Lnk-deficient mice show that Lnk-null HSCs are expanded during postnatal development (Ema et al., 2005; Buza-Vidas et al., 2006). The Lnk-/- HSC population 
contains an increased proportion of quiescent cells and shows decelerated cell cycle kinetics and enhanced resistance to repeat treatment with 5-FU in vivo compared with wild-type HSCs. Genetic evidence demonstrates that Lnk controls HSC self-renewal and quiescence, predominantly through c-Mpl. Furthermore, Lnk-deficient HSCs show higher levels of symmetric proliferation in response to thrombopoietin (TPO) in ex vivo culture than wildtype HSCs (Seita et al., 2007). Biochemical analyses revealed that Lnk directly binds to phosphorylated tyrosine residues in JAK2 after TPO stimulation (Bersenev et al., 2008). Therefore, Lnk is a physiologic negative regulator of JAK2 in HSCs, and TPO/c$\mathrm{Mpl} / \mathrm{JAK} 2 /$ Lnk constitute a major regulatory pathway controlling HSC quiescence and selfrenewal.

\subsubsection{Myc}

Human c-MYC was the second proto-oncogene to be identified and encodes a basic helixloop-helix leucine zipper transcription factor (c-Myc) (Sheiness et al., 1978). Overexpression of one of the three family members has been detected in numerous human cancers including Burkitt's lymphoma (c-MYC), neuroblastoma (N-MYC), and small cell lung cancer (L-MYC) (Nesbit et al., 1999). Conditional deletion of c-Myc in the BM results in cytopenia and the accumulation of functionally defective HSCs. In the absence of c-Myc, HSC differentiation into more committed progenitors is inhibited because they upregulate a number of adhesion molecules, such as N-cadherin, that anchor them in the niche. Conversely, enforced c-Myc expression in HSCs causes marked repression of N-cadherin and integrin expression leading to the loss of self-renewal ability at the expense of differentiation (Wilson et al., 2004). These results suggest that c-Myc activity controls the first differentiation step of LT-HSCs in vivo. Unexpectedly, conditional ablation of both c-myc and N-myc results in pancytopenia and rapid lethality due to HSC apoptosis via the accumulation of the cytotoxic molecule, Granzyme B (Laurenti et al., 2008). Thus, Myc activity controls important aspects of HSC function such as proliferation, survival and differentiation.

\subsubsection{MEF/ELF4}

MEF (also known as ELF4), an Ets transcription factor, was identified as a novel component of the transcriptional circuit that dynamically regulates HSC quiescence (Lacorazza et al., 2006). Mef-deficient HSCs grow more slowly than wild-type HSCs in response to cytokine stimulation Pyronin $\mathrm{Y}$ staining and BrdU incorporation show increased quiescence. Enhanced HSC quiescence in Mef-null mice also increases HSC resistance to cytotoxic agents that target dividing cells and allows more rapid hematological recovery after chemotherapy or irradiation. These findings suggest that Mef normally functions to induce or facilitate the entry of quiescent HSCs into the cell cycle and imply that Mef expression and/or activity may be dynamically regulated in HSCs. To explain this, Lacorazza et al. proposed a model in which Mef acts at an earlier stage than p18 and antagonizes p21.

\subsection{Survival of HSCs}

HSC self-renewal and apoptosis represent major factors that determine the size of the HSC mass. The number of HSCs is also controlled by their capacity to survive during homeostasis or under conditions of stress. 


\subsubsection{Bcl-2 family}

Accumulating evidence suggests that the suppression of apoptosis is required for HSC survival. Forced expression of Bcl-2 increases the number of HSCs and provides them with enhanced competitive repopulation ability (Domen et al., 1998, 2000), suggesting that cell death plays a role in regulating HSC homeostasis.

Mcl-1, another anti-apoptotic Bcl-2 family member, is also an essential regulator of HSC survival. Mcl-1 is highly expressed in LT-HSCs, and conditional deletion of MCl-1 results in the loss of the early BM progenitor population, including HSCs, leading to fatal hematopoietic failure (Opferman et al., 2005). Recently, it was reported that Mcl-1 is an indispensable regulator of self-renewal in human stem cells and that functional dependence on Mcl-1 defines the human stem cell hierarchy (Campbell et al., 2010).

\subsubsection{Scl, Lyl1}

$\mathrm{Scl} / \mathrm{Tal1}$ is a basic helix-loop-helix (bHLH) transcription factor that is essential for the development of HSCs in the embryo (Robb et al., 1995; Shivdasani et al., 1995). During adult hematopoiesis, Scl/Tal1 is highly expressed in LT-HSCs compared with short-term HSCs and progenitor cells (Lacombe et al., 2010). However, a study using conditional Scl/Tal1 knockout mice revealed that $\mathrm{Scl} / \mathrm{Tal} 1$ is required for the generation of, but not the maintenance of, adult HSCs (Mikkola et al., 2003). Another group showed that conditional deletion of Scl/Tal1 in adult HSCs has a relatively mild effect: Scl-null HSCs show impaired short-term repopulating ability, but no defect in long-term repopulating capacity (Curtis et al., 2004). Redundant activity caused by the expression of Lyl1, a related bHLH transcription factor, in adult HSCs may provide an explanation for these "mild" phenotypes. While adult HSCs in single-knockout mice show no or only a mild phenotype, Lyl1;Scl-conditional double-knockout mice show a gene dosage defect on HSC survival, as HSCs and progenitor cells are immediately lost due to apoptosis (Souroullas et al., 2009).

Recently, Lacombe et al. demonstrated that Scl/Tal1 is required for the maintenance of the quiescent stem cell pool (Lacombe et al., 2010). Cell-cycle analyses revealed that Scl/Tal1 negatively regulates the G0-G1 transit of LT-HSCs; however, these phenomena were specific to adult HSCs and were not observed in perinatal HSCs. The reconstituting ability of $\mathrm{Scl}^{+}-$ HSCs or HSCs with decreased Scl protein expression induced by RNA interference was impaired in various transplantation assays. Furthermore, gene expression analysis and chromatin immunoprecipitation experiments revealed that the Cdkn1a and Id1 genes are direct SCL targets.

\subsubsection{Tel/Etv6}

The transcription factor Tel (also known as Etv6), an Ets-related transcriptional repressor, is a frequent target of the diverse chromosomal translocations observed in leukemias (Golub et al., 1994). Tel/ETV6 is also required for HSC survival in adult hematopoiesis. Following conditional inactivation of Tel/Etv6, HSCs are rapidly lost from the adult BM. However, Tel/Etv6 is not required for the maintenance of lineage-committed progenitors. Conditional deletion of Tel/Etv6 after lineage commitment does not affect the differentiation or survival of these progenitors, although it does impair the maturation of megakaryocytes (Hock et al., 2004). 


\subsubsection{Zfx}

$\mathrm{Zfx}$ is a zinc finger protein belonging to the $\mathrm{Zfx} / \mathrm{ZFy}$ family. Mammalian Zfx is encoded on the $X$ chromosome and contains an acidic transcriptional activation domain, a nuclear localization sequence, and a DNA binding protein domain consisting of $13 \mathrm{C} 2 \mathrm{H} 2$-type zinc fingers (Schneider-Gadicke et al., 1989). Zfx is highly expressed in both HSCs and undifferentiated embryonic stem cells (ESCs). Using conditional gene targeting, Zfx was identified as an essential transcriptional regulator of HSC function (Galan-Caridad et al., 2007). Constitutive or inducible deletion of Zfx in HSCs (using Tie2-Cre and Mx1-Cre deletion strains, respectively) impairs self-renewal, resulting in increased apoptosis and the upregulation of stress-inducible genes.

\subsubsection{ADAR1}

ADAR (adenosine deaminase acting on RNA) catalyzes the deamination of adenosine to inosine in double-stranded RNA. Conventional Adar $/$ mice die around embryonic day 11.5-12 because of widespread apoptosis and defective hematopoiesis (Hartner et al., 2004; Wang et al., 2004). Conditional deletion of Adar in HSCs shows that ADAR1 is essential for the maintenance of both fetal and adult HSCs, and leads to global upregulation of type I and II interferon-inducible transcripts and rapid apoptosis (Hartner et al., 2009). Interferon regulatory factor-2 (Irf2), a transcriptional suppressor of type I interferon signaling, is a positive regulator of HSC quiescence (Sato et al., 2009). Irf2-deficient HSCs are unable to restore hematopoiesis in irradiated mice, but the reconstituting capacity of $\operatorname{Irf2} \%$ - HSCs can be restored in these cells by disabling type I IFN signaling.

\subsection{Response to hematopoietic emergency}

Various external stresses, such as myelosuppressive chemotherapy, bleeding, infection, and total body irradiation, put HSCs under stress, as they must proliferate to produce large numbers of primitive progenitor cells, thereby enabling rapid hematologic regeneration. Although this property has long been recognized, the molecular basis underlying the reaction of HSCs to hematologic emergency remains enigmatic. However, some key players have been identified.

\subsubsection{Heme oxygenase-1}

Heme promotes the proliferation and differentiation of hematopoietic progenitor cells (HPCs) (Chertkov et al., 1991) and stimulates hematopoiesis (Porter et al., 1979; Abraham, 1991). The degradation of heme is catalyzed by heme oxygenase (HO). HO-1, encoded by the Hmox 1 gene, is the stress-inducible isozyme of $\mathrm{HO}$ and is highly expressed in the spleen and BM (Abraham, 1991). Heterozygous HO-1-deficient mice $\left(\mathrm{HO}-1^{+/-}\right)$show accelerated hematologic recovery from myelotoxic injury induced by 5-FU treatment, and mice transplanted with $\mathrm{HO}-1^{+/-} \mathrm{BM}$ cells show more rapid hematopoietic repopulation than those transplanted with $\mathrm{Ho}-\mathrm{1}^{+/+} \mathrm{BM}$ cells. However, $\mathrm{HO}-1^{+/-} \mathrm{HSC}$ show a reduced capacity to rescue lethally irradiated mice and to serially repopulate irradiated recipients (Cao et al., 2008). These results suggest that HO-1 limits the proliferation and differentiation of HPCs under stressful conditions, and that the failure of this mechanism can lead to the premature exhaustion of the HSC pool. 


\subsubsection{Necdin}

Necdin is a member of the melanoma antigen family of molecules, whose physiological roles have not been well characterized (Xiao et al., 2004). Necdin acts as a cell cycle regulator in post-mitotic neurons (Yoshikawa, 2000). Intriguingly, recent genetic analyses show that aberrant genomic imprinting of NDN on the human 15q11-q13 chromosomal region is, at least in part, responsible for the pathogenesis of Prader-Willi syndrome (MacDonald \& Wevrick, 1997; Nakada et al., 1998; Barker et al., 2002), a disorder associated with a mildly increased risk of myeloid leukemia (Davies et al., 2003). Necdin interacts with multiple cell-cycle related proteins, such as SV-40 large $\mathrm{T}$ antigen, adenovirus E1A, E2F1, and p53 (Taniura et al., 1998, 1999, 2005; Hu et al., 2003). As shown in Table 2, necdin is one of 32 genes that show higher expression in HSCs than in differentiated hematopoietic cells (Kubota et al., 2009). Other groups also found that necdin is highly expressed in HSCs (Forsberg et al., 2005; Liu et al., 2009). Necdindeficient mice show accelerated recovery of hematopoietic systems after myelosuppressive stress, such as 5-FU treatment and BM transplantation, whereas no overt abnormality is seen under conditions of steady-state hematopoiesis. Considering necdin as a potential negative cell-cycle regulator, it was reasoned that the enhanced hematologic recovery in necdin-null mice could be the result of an increased number of proliferating HSCs and progenitor cells. As expected, after 5-FU treatment, necdindeficient mice had an increased number of HSCs, but this was only transiently observed during the recovery phase (Kubota et al., 2009). These data suggest that the repression of necdin function in HSCs may present a novel strategy for accelerating hematopoietic recovery, thus providing therapeutic benefits after clinical myelosuppressive treatments (e.g., cytoablative chemotherapy or HSC transplantation).

\subsubsection{Slug}

Slug belongs to the highly conserved Slug/Snail family of zinc-finger transcriptional repressors found in diverse species ranging from C. elegans to humans. SLUG is a target gene for the E2A-HLF chimeric oncoprotein in pro-B cell acute leukemia (Inukai et al., 1999). Slug-deficient mice show normal peripheral blood counts, but they are very sensitive to $\gamma$ irradiation (Inoue et al., 2002). Slug is induced by p53 and protects primitive hematopoietic cells from apoptosis triggered by DNA damage. Slug exerts this function by repressing Puma, a proapoptotic target of p53 (Wu et al., 2005). Sun et al. recently showed that Slug negatively regulates the repopulating ability of HSCs under conditions of stress. Slug deficiency increases HSC proliferation and reconstitution potential in vivo after myelosuppressive treatment, and accelerates HSC expansion during in vitro culture (Sun et al., 2010).

\section{Cancer stem cells}

Accumulating evidence strongly suggests that tumors are organized into cellular hierarchies initiated and maintained by a small pool of self-renewing cancer stem cells (CSCs) (Dick, 2008; Reya et al., 2001). CSCs are thought to be resistant to various cancer treatments because of their relative quiescence (Komarova \& Wodarz., 2007). Cancer relapses may occur because the dormancy of CSCs protects them from elimination by various cancer 
therapies (Dick, 2008). In an acute myelogenous leukemia (AML) xenograft model, AML leukemic stem cells (LSCs) localized in the endosteal region of the BM show cellular quiescence and resistance to chemotherapy (Ishikawa et al., 2007; Saito et al., 2010). In patients with chronic myelogenous leukemia (CML), CD34 ${ }^{+}$progenitor cells contain dormant cells that are resistant to BCR/ABL tyrosine kinase inhibitors (Bhatia et al., 2003).

It is well documented that regulators of HSC maintenance are also involved in the development of leukemias (Rizo et al., 2006). A number of cancer-related proteins, such as Bmi1, c-Myc, p53, Gfi-1, and PTEN, are key participants in HSC regulation, demonstrating the close relationship between normal HSCs and CSCs. Therefore, further understanding the mechanisms regulating HSC fate is needed if we are to develop new strategies for targeting CSCs and successfully treat cancer.

\section{Conclusions}

In this review, we have briefly summarized a number of critical regulators involved in the control of HSC self-renewal, quiescence, survival, and responses to external insults. Recent evidence strongly suggests that the BM niche also plays an integral role by providing critical signals that maintain HSCs in a stat of hibernation, thus preventing them from exhausting themselves. However, HSCs are critical for the maintenance and regeneration of an organism after injury/illness. This process must be tightly regulated and coordinated. Intensive studies have uncovered the molecular signatures and key molecules regulating HSC behavior. Moreover, new systems approaches, such as microRNA expression profiling and protein expression profiling, are expected to provide further useful information about HSC biology in the future. However, the overall picture of the molecular mechanisms that govern HSC fate is still unclear. Further understanding of the systems that regulate HSCs will enable the manipulation of stem cells for use in tissue engineering and cell-based therapies.

\section{Acknowledgments}

This work was supported by a Grant-in-Aid for Young Scientists to Y.K. (no. 23791083) from the Ministry of Education, Culture, Sports, Science and Technology (MEXT), Japan.

\section{References}

Abraham, N.G. (1991) Molecular regulation--biological role of heme in hematopoiesis. Blood Rev 5(1):19-28.

Akashi, K., Traver, D., Miyamoto, T., \& Weissman, I.L. (2000) A clonogenic common myeloid progenitor that gives rise to all myeloid lineages. Nature 404(6774):193-197.

Akashi, K., He, X., Chen, J., Iwasaki, H., Niu, C., Steenhard, B., Zhang, J., Haug, J., \& Li, L. (2003) Transcriptional accessibility for genes of multiple tissues and hematopoietic lineages is hierarchically controlled during early hematopoiesis. Blood 101(2):383389.

Barker, P.A., \& Salehi, A. (2002) The MAGE proteins: emerging roles in cell cycle progression, apoptosis, and neurogenetic disease. J Neurosci Res 67(6):705-712. 
Bernassola, F., Karin, M., Ciechanover, A., \& Melino, G. (2008) The HECT family of E3 ubiquitin ligases: multiple players in cancer development. Cancer Cell 14(1):10-21.

Bersenev, A., Wu, C., Balcerek, J., \& Tong, W. (2008) Lnk controls mouse hematopoietic stem cell self-renewal and quiescence through direct interactions with JAK2. J Clin Invest 118(8):2832-2844.

Bhatia, R., Holtz, M., Niu, N., Gray, R., Snyder, D.S., Sawyers, C.L., Arber, D.A., Slovak, M.L., \& Forman, S.J. (2003) Persistence of malignant hematopoietic progenitors in chronic myelogenous leukemia patients in complete cytogenetic remission following imatinib mesylate treatment. Blood 101(12):4701-4707.

Buza-Vidas, N., Antonchuk, J., Qian, H., Månsson, R.,Luc, S., Zandi, S., Anderson, K., Takaki, S., Nygren, J.M., Jensen, C.T., \& Jacobsen S.E. (2006) Cytokines regulate postnatal hematopoietic stem cell expansion: opposing roles of thrombopoietin and LNK. Genes Dev 20(15):2018-2023.

Campbell, C.J.V., Lee, J.B., Levadoux-Martin, M., Wynder, T., Xenocostas, A., Leber, B., \& Bhatia, M. (2010) The human stem cell hierarchy is defined by a functional dependence on Mcl-1 for self-renewal capacity. Blood 116(9):1433-1442.

Cao, Y.A., Wagers, A.J., Karsunky, H., Zhao, H., Reeves, R., Wong, R.J., Stevenson, D.K., Weissman, I.L., \& Contag, C.H. (2008) Heme oxygenase-1 deficiency leads to disrupted response to acute stress in stem cells and progenitors. Blood 112(12):44944502.

Chambers, S.M., Boles, N.C., Lin, K.Y., Tierney, M.P., Bowman, T.V., Bradfute, S.B., Chen, A.J., Merchant, A.A., Sirin, O., Weksberg, D.C., Merchant, M.G., Fisk, C.J., Shaw, C.A., \& Goodell, M.A. (2007) Hematopoietic fingerprints: an expression database of stem cells and their progeny. Cell Stem Cell 1(5): 578-591.

Chen, J., Ellison, F.M., Keyvanfar, K., Omokaro, S.O., Desierto, M.J., Eckhaus, M.A., \& Young, N.S. (2008) Enrichment of hematopoietic stem cells with SLAM and LSK markers for the detection of hematopoietic stem cell function in normal and Trp53 null mice. Exp Hematol 36(10):1236-1243.

Cheng, T., Rodrigues, N., Shen, H., Yang, Y., Dombkowski, D., Sykes, M., \& Scadden D.T. (2000) Hematopoietic stem cell quiescence maintained by p21cip1/waf1. Science 287(5459):1804-1808.

Chertkov, J.L., Jiang, S., Lutton, J.D., Levere, R.D., \& Abraham, N.G. (1991) Hemin stimulation of hemopoiesis in murine long-term bone marrow culture. Exp Hematol 19(9):905-909.

Cheshier, S.H., Morrison, S.J., Liao, X., \& Weissman, I.L. In vivo proliferation and cell cycle kinetics of long-term self-renewing hematopoietic stem cells. (1999) Proc Natl Acad Sci U S A 96(6):3120-3125.

Curtis, D.J., Hall, M.A., Van Stekelenberg, L.J., Robb, L., Jane, S.M., \& Begley, C.G. (2004) $\mathrm{SCL}$ is required for normal function of short-term repopulating hematopoietic stem cells. Blood 103(9):3342-3348.

Davies, H.D., Leusink, G.L., McConnell, A., Deyell, M., Cassidy, S.B., Fick, G.H., \& Coppes, M.J. (2003) Myeloid leukemia in Prader-Willi syndrome. J Pediatr 142(2):174-178.

Dick, J.E. (2008) Stem cell concepts renew cancer research. Blood 112(13):4793-4807.

DiMartino, J.F., Selleri, L., Traver, D., Firpo, M.T., Rhee, J., Warnke, R., O'Gorman, S., Weissman, I.L., \& Cleary, M.L. (2001) The Hox cofactor and protooncogene Pbx1 is 
required for maintenance of definitive hematopoiesis in the fetal liver. Blood 98:618-626.

Domen, J., Gandy, K.L., \& Weissman, I.L. (1998) Systemic overexpression of BCL-2 in the hematopoietic system protects transgenic mice from the consequences of lethal irradiation. Blood 91(7):2272-2282.

Domen, J., Cheshier, S.H., \& Weissman, I.L. (2000) The role of apoptosis in the regulation of hematopoietic stem cells: Overexpression of Bcl-2 increases both their number and repopulation potential. J Exp Med 191(2):253-264.

Dumble, M., Moore, L., Chambers, S.M., Geiger, H., Zant, G.V., Goodell, M.A. \& Donehower, L.A. (2007) The impact of altered p53 dosage on hematopoieitic stem cell dynamics during aging. Blood 109(4):1736-1742.

Ema, H., Sudo, K., Seita, J., Matsubara, A., Morita, Y., Osawa, M., Takatsu, K., Takaki, S., \& Nakauchi, H. (2005) Quantification of self-renewal capacity in single hematopoietic stem cells from normal and Lnk-deficient mice. Dev Cell 8(6):907-914.

Ficara, F., Murphy, M.J., Lin, M., \& Cleary, M.L. (2008) Pbx1 regulates self-renewal of longterm hematopoietic stem cells by maintaining their quiescence. Cell Stem Cell 2(5):484-496.

Forsberg, E.C., Prohaska, S.S., Katzman, S., Heffner, G.C., Stuart, J.M., \& Weissman, I.L. (2005) Differential expression of novel potential regulators in hematopoietic stem cells. PLoS Genet 1(3):e28.

Galan-Caridad, J.M., Harel, S., Arenzana, T.L., Hou, Z.E., Doetsch, F.K., Mirny, L.A., \& Reizis, B. (2007) Zfx controls the self-renewal of embryonic and hematopoietic stem cells. Cell 129(2):345-357.

Gan, B., Hu, J., Jiang, S., Liu, Y., Sahin, E., Zhuang, L., Fletcher-Sananikone, E., Colla, S., Wang, Y.A., Chin, L., \& Depinho, R.A. (2010) Lkb1 regulates quiescence and metabolic homeostasis of haematopoietic stem cells. Nature 468(7324):701-704.

Gashler, A., \& Sukhatme, V.P. (1995) Early growth response protein 1 (Egr-1): prototype of a zinc-finger family of transcription factors. Prog Nucleic Acid Res Mol Biol 50:191-224.

Gilks, C.B., Bear, S.E., Grimes, H.L., \& Tsichlis, P.N. (1993) Progression of interleukin-2 (IL2)-dependent rat $T$ cell lymphoma lines to IL-2-independent growth following activation of a gene (Gfi-1) encoding a novel zinc finger protein. Mol Cell Biol 13(3): 1759-1768.

Golub,T.R., Barker, G.F., Lovett, M., \& Gilliland, D.G. (1994) Fusion of PDGF receptor $\beta$ to a novel ets-like gene, tel, in chronic myelomonocytic leukemia with $t(5 ; 12)$ chromosomal translocation. Cell 77(2): 307-316.

Goh, E.L., Zhu, T., Leong, W.Y., \& Lobie, P.E. (2002) c-Cbl is a negative regulator of GHstimulated STAT5-mediated transcription. Endocrinology 143(9):3590-3603.

Goyama, S., Yamamoto, G., Shimabe, M., Sato, T., Ichikawa, M., Ogawa, S., Chiba, S., \& Kurokawa, M. (2008) Evi-1 is a critical regulator for hematopoietic stem cells and transformed leukemic cells. Cell Stem Cell 3(2):207-220.

Greer, E.L., \& Brunet, A. (2005) FOXO transcription factors at the interface between longevity and tumor suppression. Oncogene 24(50):7410-7425.

Gurumurthy, S., Xie, S.Z., Alagesan, B., Kim, J., Yusuf, R.Z., Saez, B., Tzatsos, A., Ozsolak, F., Milos, P., Ferrari, F., Park, P.J., Shirihai, O.S., Scadden, D.T., \& Bardeesy, N. (2010) The Lkb1 metabolic sensor maintains haematopoietic stem cell survival. Nature 468(7324):659-663. 
Harper, J.W., Adami, G.R., Wei, N., Keyomarsi, K., \& Elledge, S.J. (1993) The p21 Cdkinteracting protein Cip1 is a potent inhibitor of G1 cyclin-dependent kinases. Cell 75(4):805-816.

Hartner, J.C., Schmittwolf, C., Kispert, A., Müller, A.M., Higuchi, M., \& Seeburg, P.H. (2004) Liver disintegration in the mouse embryo caused by deficiency in the RNA-editing enzyme ADAR1. J Biol Chem 279(6):4894-4902.

Hartner,J.C., Walkley, C.R., Lu, J., \& Orkin, S.H. (2009) ADAR1 is essential for the maintenance of hematopoiesis and suppression of interferon signaling. Nat Immunol 10(1):109-115.

Hisa, T., Spence, S.E., Rachel, R.A., Fujita, M., Nakamura, T., Ward, J.M., Devor-Henneman, D.E., Saiki, Y., Kutsuna, H., Tessarollo, L., Jenkins, N.A., \& Copeland, N.G. (2004) Hematopoietic, angiogenic and eye defects in Meis1 mutant animals. EMBO J 23(2):450-459.

Hock, H., Meade, E., Medeiros, S., Schindler, J.W., Valk, P.J.M., Fujiwara, Y., \& Orkin, S.H. (2004) Tel/Etv6 is an essential and selective regulator of adult hematopoietic stem cell survival. Genes Dev 18(19):2336-2341.

Hock, H., Hamblen, M.J., Rooke, H.M., Schindler, J.W., Saleque, S., Fujiwara, Y., \& Orkin, S.H. (2004) Gfi-1 restricts proliferation and preserves functional integrity of haematopoietic stem cells. Nature 431(7011):1002-1007.

Hu, B., Wang, S., Zhang, Y., Feghali, C.A., Dingman, J.R., \& Wright, T.M. (2003) A nuclear target for interleukin-1alpha: interaction with the growth suppressor necdin modulates proliferation and collagen expression. Proc Natl Acad Sci U S A 100(17):10008-10013.

Inoue, A., Seidel, M.G., Wu, W., Kamizono, S., Ferrando, A.A., Bronson, R.T., Iwasaki, H., Akashi, K., Morimoto, A., Hitzler, J.K., Pestina, T.I., Jackson, C.W., Tanaka, R., Chong, M.J., McKinnon, P.J., Inukai, T., Grosveld, G.C., \& Look, A.T. (2002) Slug, a highly conserved zinc finger transcriptional repressor, protects hematopoietic progenitor cells from radiation-induced apoptosis in vivo. Cancer Cell 2(4):279-288.

Inukai, T., Inoue, A., Kurosawa, H., Goi, K., Shinjyo,T., Ozawa, K., Mao, M., Inaba, T., \& Look, A.T. (1999) SLUG, a ces-1-related zinc finger transcription factor gene with antiapoptotic activity, is a downstream target of the E2A-HLF oncoprotein. Mol Cell 4(3):343-352.

Ishikawa, F., Yoshida, S., Saito, Y., Hijikata, A., Kitamura, H., Tanaka, S., Nakamura, R., Tanaka, T., Tomiyama, H., Saito, N., Fukata, M., Miyamoto, T., Lyons, B., Ohshima, K., Uchida, N., Taniguchi, S., Ohara, O., Akashi, K., Harada, M., \& Shultz, L.D. (2007) Chemotherapy-resistant human AML stem cells home to and engraft within the bone-marrow endosteal region. Nat Biotechnol 25(11):1315-1321.

Ivanova, N.B., Dimos, J.T., Schaniel, C., Hackney, J.A., Moore, K.A., \& Lemischka, I.R. (2002) A stem cell molecular signature. Science 298(5593):601-604.

Iwama, A., Oguro, H., Negishi, M., Kato, Y., Morita, Y., Tsukui, H., Ema, H., Kamijo, T., Katoh-Fukui, Y., Koseki, H., van Lohuizen, M., \& Nakauchi, H. (2004) Enhanced self-renewal of hematopoietic stem cells mediated by the polycomb gene product Bmi-1. Immunity 21(6):843-851.

Jacobs, J.J.L., Kieboom, K., Marino, S., DePinho, R.A., \& van Lohuizen, M. (1999) The oncogene and Polycomb-group gene bmi1 regulates proliferation and senescence through the ink4a locus. Nature 397(6715):164-168. 
Jehn, B.M., Dittert, I., Beyer, S., von der Mark, K., \& Bielke, W. (2002) c-Cbl binding and ubiquitin-dependent lysosomal degradation of membrane-associated Notch1. J Biol Chem 277(10):8033-8040.

Kaelin, W.G., Jr., \& Ratcliffe, P.J. (2008) Oxygen sensing by metazoans: the central role of the HIF hydroxylase pathway. Mol Cell 30(4):393-402.

Kastan, M.B., Radin, A.I., Kuerbitz, S.J., Onyekwere, O., Wolkow, C.A., Civin, C.I., Stone, K.D., Woo, T., Ravindranath, Y., \& Craig, R.W. (1991) Levels of p53 protein increase with maturation in human hematopoietic cells. Cancer Res 51(16):4279-4286.

Kiel, M.J., Yilmaz, O.H., Iwashita, T., Yilmaz, O.H., Terhorst, C., \& Morrison, S.J. (2005) SLAM family receptors distinguish hematopoietic stem and progenitor cells and reveal endothelial niches for stem cells. Cell 121(7):1109-1121.

Kimura, S., Roberts, A.W., Metcalf, D., \& Alexander, W.S. (1998) Hematopoietic stem cell deficiencies in mice lacking c-Mpl, the receptor for thrombopoietin. Proc Natl Acad Sci USA 95(3):1195-1200.

Komarova, N.L., \& Wodarz, D. (2007) Effect of cellular quiescence on the success of targeted CML therapy. PLoS One 2(10):e990.

Kondo, M., Wagers, A.J., Manz, M.G., Prohaska, S.S., Scherer, D.C., Beilhack, G.F., Shizuru, J.A., \& Weissman, I.L. (2003) Biology of hematopoietic stem cells and progenitors: implications for clinical application. Annu Rev Immunol 21:759-806.

Kubota, Y., Osawa, M., Jakt, L.M., Yoshikawa, K., \& Nishikawa, S-I. (2009) Necdin restricts proliferation of hematopoietic stem cells during hematopoietic regeneration. Blood 114(20):4383-4392.

Lacombe, J., Herblot, S., Rojas-Sutterlin, S., Haman, A., Barakat, S., Iscove, N.N., Sauvageau, G., \& Hoang, T. (2010) Scl regulates the quiescence and the long-term competence of hematopoietic stem cells. Blood 115(4):792-803.

Lacorazza, H.D., Yamada, T., Liu, Y., Miyata, Y., Sivina, M., Nunes, J., \& Nimer, S.D. (2006) The transcription factor MEF/ELF4 regulates the quiescence of primitive hematopoietic cells. Cancer Cell 9(3):175-187.

Laurenti, E., Varnum-Finney, B., Wilson, A., Ferrero, I., Blanco-Bose, W.E., Ehninger, A., Knoepfler, P.S., Cheng, P.F., MacDonald, H.R., Eisenman, R.N., Bernstein, I.D., \& Trumpp, A. (2008) Hematopoietic stem cell function and survival depend on c-Myc and N-Myc activity. Cell Stem Cell 3(6):611-624.

Liu, Y., Elf, S.E., Miyata, Y., Sashida, G., Liu, Y., Huang, G., Di Giandomenico, S., Lee, J.M., Deblasio, A., Menendez, S., Antipin, J., Reva, B., Koff, A., \& Nimer, S.D. (2009) p53 regulates hematopoietic stem cell quiescence. Cell Stem Cell 4(1):37-48.

Lotem, J., \& Sachs, L. (1993) Hematopoietic cells from mice deficient in wild-type p53 are more resistant to induction of apoptosis by some agents. Blood 82(4):1092-1096.

MacDonald, H.R. \& Wevrick, R. (1997) The necdin gene is deleted in Prader-Willi syndrome and is imprinted in human and mouse. Hum Mol Genet 6(11):1873-1878.

Matsuoka, S., Oike, Y., Onoyama, I., Iwama, A., Arai, F., Takubo, K., Mashimo, Y., Oguro, H., Nitta, E., Ito, K., Miyamoto, K., Yoshiwara, H., Hosokawa, K., Nakamura, Y., Gomei, Y., Iwasaki, H., Hayashi, Y., Matsuzaki, Y., Nakayama, K., Ikeda, Y., Hata, A., Chiba, S., Nakayama, K.I., \& Suda, T. (2008) Fbxw7 acts as a critical fail-safe against premature loss of hematopoietic stem cells and development of T-ALL. Genes Dev 22(8):986-991. 
Mikkola, H.K., Klintman, J., Yang, H., Hock, H., Schlaeger, T.M., Fujiwara, Y., \& Orkin, S.H. (2003) Haematopoietic stem cells retain long-term repopulating activity and multipotency in the absence of stem-cell leukaemia SCL/tal-1 gene. Nature 421(6922):547-551.

Min, I.M., Pietramaggiori, G., Kim, F.S., Passegué, E., Stevenson, K.E., \& Wagers, A,J. (2008) The transcription factor EGR1 controls both the proliferation and localization of hematopoietic stem cells. Cell Stem Cell 2(4):380-391.

Miyamoto, K., Araki, K.Y., Naka, K., Arai, F., Takubo, K., Yamazaki, S., Matsuoka, S., Miyamoto, T., Ito, K., Ohmura, M., Chen, C., Hosokawa, K., Nakauchi, H., Nakayama, K., Nakayama, K.I., Harada, M., Motoyama, N., Suda, T., \& Hirao, A. (2007) Foxo3a is essential for maintenance of the hematopoietic stem cell pool. Cell Stem Cell 1(1):101-112.

Morishita, K., Parker, D.S., Mucenski, M.L., Jenkins, N.A., Copeland, N.G., \& Ihle, J.N. (1988) Retroviral activation of a novel gene encoding a zinc finger protein in IL-3dependent myeloid leukemia cell lines. Cell 54(6):831-840.

Mucenski, M.L., Taylor, B.A., Ihle, J.N., Hartley, J.W., Morse, H.C., Jenkins, N.A., Copeland, N.G. (1988) Identification of a common ecotropic viral integration site, Evi-1, in the DNA of AKXD murine myeloid tumors. Mol Cell Biol 8(1):310-308.

Nakada, D., Saunders, T.L., \& Morrison, S.J. (2010) Lkb1 regulates cell cycle and energy metabolism in haematopoietic stem cells. Nature 468(7324):653-658.

Nakada, Y., Taniura, H., Uetsuki, T., Inazawa, J., \& Yoshikawa, K. (1998) The human chromosomal gene for necdin, a neuronal growth suppressor, in the Prader-Willi syndrome deletion region. Gene 213(1-2):65-72.

Nesbit, C.E., Tersak, J.M., \& Prochownik, E.V. (1999) MYC oncogenes and human neoplastic disease. Oncogene 18(19):3004-3016.

Oguro, H., Iwama, A., Morita, Y., Kamijo, T., van Lohuizen, M., \& Nakauchi, H. (2006) Differential impact of Ink4a and Arf on hematopoietic stem cells and their bone marrow microenvironment in Bmi1-deficient mice. J Exp Med 203(10):2247-2253.

Opferman, J.T., Iwasaki, H., Ong, C.C., Suh, H., Mizuno, S., Akashi, K., \& Korsmeyer, S.J. (2005) Obligate role of anti-apoptotic MCL-1 in the survival of hematopoietic stem cells. Science 307(5712):1101-1104.

Orford, K.W., \& Scadden, D.T. (2008) Deconstructing stem cell self-renewal: genetic insights into cell-cycle regulation. Nat Rev Genet 9(2):115-128.

Osawa, M., Hanada, K., Hamada, H., \& Nakauchi, H. (1996) Long-term lymphohematopoietic reconstitution by a single CD34-low/negative hematopoietic stem cell. Science 273(5272):242-245.

Park, I.K., He, Y., Lin, F., Laerum, O.D., Tian, Q., Bumgarner, R., Klug, C.A., Li, K., Kuhr, C., Doyle, M.J., Xie, T., Schummer, M., Sun, Y., Goldsmith, A., Clarke, M.F., Weissman, I.L., Hood, L., \& Li, L. (2002) Differential gene expression profiling of adult murine hematopoietic stem cells. Blood 99(2):488-498.

Park, I.K., Qian, D., Kiel, M., Becker, M.W., Pihalja, M., Weissman, I.L., Morrison, S.J., \& Clarke, M.F. (2003) Bmi-1 is required for maintenance of adult self-renewing haematopoietic stem cells. Nature 423(6937):302-305.

Passegué E., Jochum W., Schorpp-Kistner M., Möhle-Steinlein U., \& Wagner E.F. (2001) Chronic Myeloid Leukemia with Increased Granulocyte Progenitors in Mice Lacking JunB Expression in the Myeloid Lineage. Cell 104(1):21-32. 
Porter, P.N., Meints, R.H., \& Mesner,K. (1979) Enhancement of erythroid colony growth in culture by hemin. Exp Hematol 7(1):11-16.

Rajasekhar, V.K., Begemann, M. (2007) Concise review: roles of polycomb group proteins in development and disease: a stem cell perspective. Stem Cells 25(10):2498-2510.

Ramalho-Santos, M., Yoon, S., Matsuzaki, Y., Mulligan, R.C., \& Melton, D.A. (2002) "Stemness": transcriptional profiling of embryonic and adult stem cells. Science 298(5593):597-600.

Ramos, C.A., Bowman, T.A., Boles, N.C., Merchant, A.A., Zheng, Y., Parra, I., Fuqua, S.A., Shaw, C.A., \& Goodell, M.A. (2006) Evidence for diversity in transcriptional profiles of single hematopoietic stem cells. PLoS Genet 2(9):e159.

Randall, T.D., \& Weissman, I.L. (1997) Phenotypic and functional changes induced at the clonal level in hematopoietic stem cells after 5-fluorouracil treatment. Blood 89(10):3596-3606.

Rathinam, C., Thien, C.B., Langdon, W.Y., Gu,H., \& Flavell, R.A. (2008) The E3 ubiquitin ligase $\mathrm{c}-\mathrm{Cbl}$ restricts development and functions of hematopoietic stem cells. Genes Dev 22(8):992-997.

Rathinam, C., Matesic, L.E., \& Flavell, R.A. (2011) The E3 ligase Itch is a negative regulator of the homeostasis and function of hematopoietic stem cells. Nat Immunol 12(5):399407.

Reya, T., Morrison, S.J., Clarke, M.F., \& Weissman, I.L. (2001) Stem cells, cancer, and cancer stem cells. Nature 414(6859):105-111.

Rizo, A., Vellenga, E., de Haan, G., \& Schuringa, J.J. (2006) Signaling pathways in selfrenewing hematopoietic and leukemic stem cells: do all stem cells need a niche? Hum Mol Genet 15 Spec No 2:R210-9.

Robb, L., Lyons, I., Li, R., Hartley, L., Köntgen, F., Harvey, R.P., Metcalf, D., \& Begley, C.G. (1995) Absence of yolk sac hematopoiesis from mice with a targeted disruption of the scl gene. Proc Natl Acad Sci U S A 92(15):7075-7079.

Rodrigues, N.P., Janzen, V., Forkert, R., Dombkowski, D.M., Boyd, A.S., Orkin, S.H., Enver, T., Vyas, P., \& Scadden, D.T. (2005) Haploinsufficiency of GATA-2 perturbs adult hematopoietic stem cell homeostasis. Blood 106(2):477-484.

Rudd, C.E. (2001) Lnk adaptor: novel negative regulator of B cell lymphopoiesis. Sci STKE 2001(85):pe1

Saito, Y., Uchida, N., Tanaka, S., Suzuki, N., Tomizawa-Murasawa, M., Sone, A., Najima, Y., Takagi, S., Aoki, Y., Wake, A., Taniguchi, S., Shultz, L.D., \& Ishikawa, F. (2010) Induction of cell cycle entry eliminates human leukemia stem cells in a mouse model of AML. Nat Biotechnol 28(3):275-280.

Santaguida, M., Schepers, K., King, B., Sabnis, A.J., Forsberg, E.C., Attema, J.L., Braun, B.S., \& Passegué, E. (2009) JunB protects against myeloid malignancies by limiting hematopoietic stem cell proliferation and differentiation without affecting selfrenewal. Cancer Cell 15(4):341-352.

Sato, T., Onai, N., Yoshihara, H., Arai, F., Suda, T., \& Ohteki, T. (2009) Interferon regulatory factor-2 protects quiescent hematopoietic stem cells from type I interferondependent exhaustion. Nat Med 15(6):696-700.

Scandura, J.M., Boccuni, P., Massagué, J., Nimer, S.D. (2004) Transforming growth factor beta-induced cell cycle arrest of human hematopoietic cells requires p57KIP2 upregulation. Proc Natl Acad Sci U S A 101(42):15231-15236. 
Schneider-Gadicke, A., Beer-Romero, P., Brown, L.G., Mardon, G., Luoh, S.W., \& Page, D.C. (1989) Putative transcription activator with alternative isoforms encoded by human ZFX gene. Nature 342(6250):708-711.

Seita, J., Ema, H., Ooehara, J., Yamazaki, S., Tadokoro, Y., Yamasaki, A., Eto, K., Takaki, S., Takatsu, K., \& Nakauchi, H. (2007) Lnk negatively regulates self-renewal of hematopoietic stem cells by modifying thrombopoietin-mediated signal transduction. Proc Natl Acad Sci U S A 104(7):2349-2354.

Serrano, M., Hannon, G.j., \& Beach, D. (1993) A new regulatory motif in cell-cycle control causing specific inhibition of cyclin D/CDK4. Nature 366(6456):740-707.

Sheiness, D., Fanshier, L., \& Bishop, J.M. (1978) Identification of nucleotide sequences which may encode the oncogenic capacity of avian retrovirus MC29. J Virol 28(2):600-610.

Shimabe, M., Goyama, S., Watanabe-Okochi, N., Yoshimi, A., Ichikawa, M., Imai, Y., \& Kurokawa, M. (2009) Pbx1 is a downstream target of Evi-1 in hematopoietic stem/ progenitors and leukemic cells. Oncogene 28(49):4364-4374.

Shivdasani, R.A., Mayer, E.L., \& Orkin, S.H. (1995) Absence of blood formation in mice lacking the T-cell leukaemia oncoprotein tal-1/SCL. Nature 373(6513):432-434.

Shounan, Y., Dolnikov, A., MacKenzie, K.L., Miller, M., Chan, Y.Y., \& Symonds, G. Retroviral transduction of hematopoietic progenitor cells with mutant p53 promotes survival and proliferation, modifies differentiation potential and inhibits apoptosis. Leukemia 10(10):1619-1628.

Simsek, T., Kocabas, F., Zheng, J., Deberardinis, R.J., Mahmoud, A.I., Olson, E.N., Schneider, J.W., Zheng, C.C., \& Sadek, H.A. (2010) The distinct metabolic profile of hematopoietic stem cells reflects their location in a hypoxic niche. Cell Stem Cell 7(9):380-390.

Sirin, O., Lukov, G.L., Mao, R., Conneely, O.M., \& Goodell, M.A. (2010) The orphan nuclear receptor Nurr1 restricts the proliferation of haematopoietic stem cells. Nat Cell Biol 12(12):1213-1219.

Souroullas. G.P., Salmon, J.M., Sablitzky, F., Curtis, D.J., \& Goodell, M.A. (2009) Adult hematopoietic stem and progenitor cells require either $\mathrm{Lyll}$ or $\mathrm{Scl}$ for survival. Cell Stem Cell 4(2):180-186.

Stier S, Cheng T, Forkert R, Lutz C, Dombkowski DM, Zhang JL, Scadden DT. (2003) Ex vivo targeting of p21Cip1/Waf1 permits relative expansion of human hematopoietic stem cells. Blood 102(4):1260-1266.

Sun, Y., Shao, L., Bai, H., Wang, Z.Z., \& Wu, W.S. (2010) Slug deficiency enhances selfrenewal of hematopoietic stem cells during hematopoietic regeneration. Blood 115(9):1709-1717.

Takeuchi, M., Kimura, S., Kuroda, J., Ashihara, E., Kawatani, M., Osada, H., Umezawa, K., Yasui, E., Imoto, M., Tsuruo, T., Yokota, A., Tanaka, R., Nagao, R., Nakahara, T., Fujiyama, Y., \& Maekawa, T. (2010) Glyoxalase-I is a novel target against Bcr-Abl ${ }^{+}$ leukemic cells acquiring stem-like characteristics in hypoxic environment. Cell Death Diff 17(7):1211-1220.

Takubo, K., Goda, N., Yamada, W., Iriuchishima, H., Ikeda, E., Kubota, Y., Shima, H., Johnson, R.S., Hirao, A., Suematsu, M., \& Suda, T. (2010) Regulation of the HIF-1a level is essential for hematopoietic stem cells. Cell Stem Cell 7(9):391-402. 
Taniura, H., Taniguchi, N., Hara, M., \& Yoshikawa, K. (1998) Necdin, a postmitotic neuronspecific growth suppressor, interacts with viral transforming proteins and cellular transcription factor E2F1. J Biol Chem 273(2):720-728.

Taniura, H., Matsumoto, K., \& Yoshikawa, K. (1999) Physical and functional interactions of neuronal growth suppressor necdin with p53. J Biol Chem 274(23):16242-16248.

Taniura, H., Kobayashi, M., \& Yoshikawa, K. (2005) Functional domains of necdin for protein-protein interaction, nuclear matrix targeting, and cell growth suppression. J Cell Biochem 94(4):804-815.

TeKippe, M., Harrison, D.E., \& Chen, J. (2003) Expansion of hematopoietic stem cell phenotype and activity in Trp53-null mice. Exp Hematol 31(6):521-527.

Thompson, B.J., Jankovic, V., Gao, J., Buonamici, S., Vest, A., Lee, J.M., Zavadil, J., Nimer, S.D., \& Aifantis, I. (2008) Control of hematopoietic stem cell quiescence by the E3 ubiquitin ligase Fbw7. J Exp Med 205(6):1395-1408.

Tipping, A. J., Pina, C., Caster, A., Hong, D., Rodrigues, N.P., Lazzari, L., May, G.E., Jacobsen, S.E., \& Enver, T. (2009) High GATA-2 expression inhibits human hematopoietic stem and progenitor cell function by effects on cell cycle. Blood 113(12): 2661-2672.

Tothova, Z., Kollipara, R., Huntly, B.J., Lee, B.H., Castrillon, D.H., Cullen, D.E., McDowell, E.P., Lazo-Kallanian, S., Williams, I.R., Sears, C., Armstrong, S.A., Passegué, E., DePinho, R.A., \& Gilliland, D.G. (2007) FoxOs are critical mediators of hematopoietic stem cell resistance to physiologic oxidative stress. Cell 128(2):325339.

Trumpp, A., Essers, M., \& Wilson, A. (2010) Awakening dormant haematopoietic stem cells. Nat Rev Immunol 10(3):201-209.

Tsai, F. Y. \& Orkin, S. H. (1997) Transcription factor GATA-2 is required for proliferation/survival of early hematopoietic cells and mast cell formation, but not for erythroid and myeloid terminal differentiation. Blood 89(10): 3636-3643.

Umemoto, T., Yamato, M., Nishida, K., Yang, J., Tano, Y., \& Okano, T. (2005) p57Kip2 is expressed in quiescent mouse bone marrow side population cells. Biochem Biophys Res Commun 337(1):14-21.

van Os, R., Kamminga, L.M., Ausema, A., Bystrykh, L.V., Draijer, D.P., van Pelt, K., Dontje, B., \& de Haan, G. (2007) A Limited role for p21Cip1/Waf1 in maintaining normal hematopoietic stem cell functioning. Stem Cells 25(4):836-843.

Venezia, T.A., Merchant,A.A., Ramos, C.A., Whitehouse, N.L., Young, A.S., Shaw, C.A., \& Goodell, M.A. (2004) Molecular signatures of proliferation and quiescence in hematopoietic stem cells. PLoS Biol 2(10): e301.

Wang, Q., Miyakoda, M., Yang, W., Khillan, J., Stachura, D.L., Weiss, M.J., \& Nishikura, K. (2004) Stress-induced apoptosis associated with null mutation of ADAR1 RNA editing deaminase gene. J Biol Chem 279(6):4952-4961.

Wilson, A., Murphy, M.J., Oskarsson, T., Kaloulis, K., Bettess, M.D., Oser, G.M., Pasche, AC., Knabenhans, C., MacDonald, H.R., \& Trumpp, A. (2004) c-Myc controls the balance between hematopoietic stem cell self-renewal and differentiation. Genes Dev 18(22):2747-2763.

Wilson, A., Laurenti, E., Oser, G., van der Wath, R.C., Blanco-Bose, W., Jaworski, M., Offner, S., Dunant, C.F., Eshkind, L., Bockamp, E., Lió, P., Macdonald, H.R., \& Trumpp, A. 
(2008) Hematopoietic stem cells reversibly switch from dormancy to self-renewal during homeostasis and repair. Cell 135(6):1118-1129.

Wilson, A., Laurenti, E., \& Trumpp, A. (2009) Balancing dormant and self-renewing hematopoietic stem cells. Curr Opin Genet Dev 19(5):461-468.

Wu, W.S., Heinrichs, S., Xu, D., Garrison, S.P., Zambetti, G.P., Adams, J.M., \& Look, A.T. (2005) Slug antagonizes p53-mediated apoptosis of hematopoietic progenitors by repressing puma. Cell 23(4):641-653.

Xiao, J., \& Chen, H.S. (2004) Biological functions of melanoma-associated antigens. World J Gastroenterol 10(13):1849-1853.

Yamazaki, S., Iwama, A., Takayanagi, S., Eto, K., Ema, H., \& Nakauchi, H. (2009) TGF-beta as a candidate bone marrow niche signal to induce hematopoietic stem cell hibernation. Blood 113(6):1250-1256.

Yoshikawa, K. (2000) Cell cycle regulators in neural stem cells and postmitotic neurons. Neurosci Res 37:1-14.

Yuasa, H., Oike, Y., Iwama, A., Nishikata, I., Sugiyama, D., Perkins, A., Mucenski, M.L., Suda, T., \& Morishita, K. (2005) Oncogenic transcription factor Evi1 regulates hematopoietic stem cell proliferation through GATA-2 expression. EMBO J 24(11):1976-1987.

Zeng, H., Yücel, R., Kosan, C., Klein-Hitpass, L., \& Möröy, T. (2004) Transcription factor Gfi1 regulates self-renewal and engraftment of hematopoietic stem cells. EMBO J 23(20): 4116-4125.

Zeng, S., Xu, Z., Lipkowitz, S., \& Longley, J.B. (2005) Regulation of stem cell factor receptor signaling by $\mathrm{Cbl}$ family proteins (Cbl-b/c-Cbl). Blood 105(1):226-232.

Zhong, J.F., Zhao, Y., Sutton, S., Su, A., Zhan, Y., Zhu, L., Yan, C., Gallaher, T., Johnston, P.B, Anderson, W.F., \& Cooke, M.P. (2005) Gene expression profile of murine long-term reconstituting vs. short-term reconstituting hematopoietic stem cells. Proc Natl Acad Sci U S A 102(7):2448-2453. 


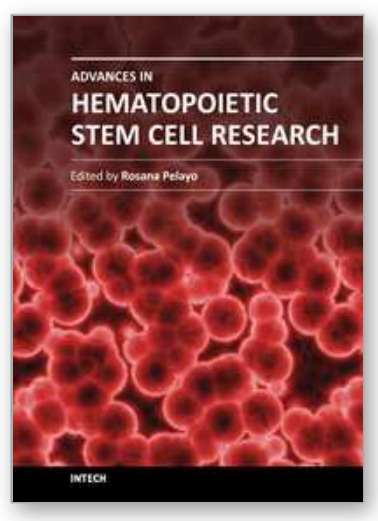

\author{
Advances in Hematopoietic Stem Cell Research \\ Edited by Dr. Rosana Pelayo
}

ISBN 978-953-307-930-1

Hard cover, 464 pages

Publisher InTech

Published online 27, January, 2012

Published in print edition January, 2012

This book provides a comprehensive overview in our understanding of the biology and therapeutic potential of hematopoietic stem cells, and is aimed at those engaged in stem cell research: undergraduate and postgraduate science students, investigators and clinicians. Starting from fundamental principles in hematopoiesis, Advances in Hematopoietic Stem Cell Research assemble a wealth of information relevant to central mechanisms that may regulate differentiation, and expansion of hematopoietic stem cells in normal conditions and during disease.

\title{
How to reference
}

In order to correctly reference this scholarly work, feel free to copy and paste the following:

Yasushi Kubota and Shinya Kimura (2012). Regulation of Hematopoietic Stem Cell Fate: Self-Renewal, Quiescence and Survival, Advances in Hematopoietic Stem Cell Research, Dr. Rosana Pelayo (Ed.), ISBN: 978-953-307-930-1, InTech, Available from: http://www.intechopen.com/books/advances-in-hematopoieticstem-cell-research/regulation-of-hematopoietic-stem-cell-fate-self-renewal-quiescence-and-survival-

\section{INTECH}

open science | open minds

\section{InTech Europe}

University Campus STeP Ri

Slavka Krautzeka 83/A

51000 Rijeka, Croatia

Phone: +385 (51) 770447

Fax: +385 (51) 686166

www.intechopen.com

\section{InTech China}

Unit 405, Office Block, Hotel Equatorial Shanghai

No.65, Yan An Road (West), Shanghai, 200040, China

中国上海市延安西路65号上海国际贵都大饭店办公楼 405 单元

Phone: +86-21-62489820

Fax: +86-21-62489821 
(C) 2012 The Author(s). Licensee IntechOpen. This is an open access article distributed under the terms of the Creative Commons Attribution 3.0 License, which permits unrestricted use, distribution, and reproduction in any medium, provided the original work is properly cited. 